\title{
PLANEJAMENTO, MONTAGEM E APLICAÇÃO DE MODELOS DIDÁTICOS PARA ABORDAGEM DE BIOLOGIA CELULAR E MOLECULAR NO ENSINO MÉDIO POR GRADUANDOS DE CIÊNCIAS BIOLÓGICAS
}

Tereza Cristina Orlando ${ }^{b}$, Adriene Ribeiro Lima ${ }^{a}$, Ariadne Mendes da Silva ${ }^{a}$, Carolina Nakau Fuzissaki ${ }^{a}$, Cíntia Lacerda Ramos ${ }^{a}$, Daisy Machado ${ }^{a}$, Fabrício Freitas Fernandes ${ }^{a}$,

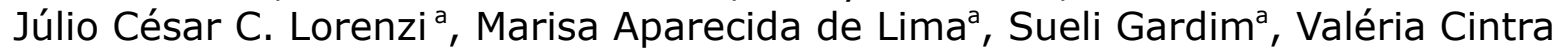
Barbosa ${ }^{a}$, Thales de A. e Tréz ${ }^{b}$.

\section{Resumo:}

Este artigo relata o processo de construção e aplicação de modelos de baixo custo na área de biologia celular e molecular. O caráter microscópico das estruturas estudadas nos conteúdos destas disciplinas torna a abordagem de ensino muitas vezes abstrata, dificultando o processo de aprendizagem. Ao mesmo tempo, a falta de laboratórios ou equipamentos em muitas escolas compromete o ensino destas disciplinas. Neste contexto, estudantes do curso de ciências biológicas da Universidade Federal de Alfenas (Unifal-MG) desenvolveram e aplicaram sete modelos em alunos do ensino médio, como material didático de apoio para a disciplina Biologia. Os resultados foram bastante positivos tanto para os estudantes do ensino médio, quanto para a equipe de graduandos.

Palavras-chave: modelos tridimensionais, ensino médio, biologia celular, biologia molecular, ensino de biologia.

\begin{abstract}
:
This article describes the process of construction and application of low-cost models in the field of cell and molecular biology. The microscopic character of the structures studied in contents of these two disciplines may turn the didactic approach into too abstractional, making the learning process difficult. At the same time, the lack of laboratories and equipments in many schools compromises the teaching of these disciplines. In this context, undergraduate students of biological sciences developed and applied seven models with secondary students at a public school used as didactic materials to support the Biology discipline content. The results were very positive both for secondary and undergraduate students.

Keywords: three-dimensional models, secondary level, cell biology, molecular biology, biology teaching.
\end{abstract}




\section{INTRODUÇÃO}

O ensino de tópicos de Biologia Celular e Molecular constitui um dos conteúdos do Ensino Médio de Biologia que mais requer a elaboração de material didático de apoio ao conteúdo presente nos livros texto, já que emprega conceitos bastante abstratos e trabalha com aspectos microscópicos. Contudo, cada dia, vemos os avanços e a importância desses conteúdos na ciência moderna e no entendimento de processos cotidianos que estão ao nosso redor e, conseqüentemente, fazem parte do dia-a-dia do estudante.

Dado o caráter microscópico dos aspectos celulares e moleculares da Biologia atual, uma abordagem ideal requer uma boa infra-estrutura de laboratório, com microscópios e aparelhagem que possibilitem a observação e estudo desses aspectos. Porém, a existência desses laboratórios é, via de regra, restrita aos colégios particulares de alto nível das grandes capitais brasileiras.

Uma alternativa para a falta desses laboratórios nas escolas, principalmente as públicas, seria a montagem de laboratórios que contivessem modelos didáticos que contemplassem os conteúdos acima e dessa forma pudessem trazer uma visão mais aproximada desse mundo abstrato aos estudantes do Ensino Médio, na ausência de equipamentos de alto custo.

Dessa forma, modelos biológicos como estruturas tridimensionais ou semi-planas (alto relevo) e coloridas são utilizadas como facilitadoras do aprendizado, complementando o conteúdo escrito e as figuras planas e, muitas vezes, descoloridas dos livros-texto. Além do lado visual, esses modelos permitem que o estudante manipule o material, visualizando-o de vários ângulos, melhorando, assim, sua compreensão sobre o conteúdo abordado. Também, a própria construção dos modelos faz com que os estudantes se preocupem com os detalhes intrínsecos dos modelos e a melhor forma de representá-los, revisando o conteúdo, além de desenvolver suas habilidades artísticas. Os modelos didáticos podem ser utilizados para enriquecer as aulas de biologia de Ensino Médio, auxiliando na compreensão do conteúdo relacionado. Os modelos despertam um maior interesse nos estudantes, uma vez que permitem a visualização do processo [1].

Também, artigos recentes têm dado bastante ênfase para a importância das atividades práticas como um valioso instrumento no ensino fundamental e médio [2, $3,4]$.

O objetivo principal deste projeto foi o de desenvolver material didático de apoio e avaliar seu uso pelos estudantes do Curso de Ciências Biológicas da UNIFAL-MG, e dos alunos na disciplina Biologia do primeiro ano do Ensino Médio da Escola Estadual Judith Viana (EEJV), localizada em Alfenas, sul de Minas Gerais.

\section{ASPECTOS METODOLógICOS}

A confeç̧ão do material didático de apoio foi realizada através da formação de grupos de estudantes do Curso de Ciências Biológicas da UNIFAL-MG que atuaram como direcionadores e incentivadores, desenvolvendo diferentes modelos para abordagem de conteúdos de Biologia Celular e Molecular nas turmas do primeiro ano do Ensino Médio da EEJV.

Para o desenvolvimento dos modelos foram utilizados livros didáticos para o Ensino Médio $[5,6]$ e livros específicos da área para o Ensino Superior $[7,8]$, para a escolha dos modelos tridimensionais e semi-planos. 
A idéia foi também a de incentivar e melhorar o conhecimento dos estudantes da EEJV sobre conteúdos básicos da Biologia Celular e Molecular através da elaboração de modelos a serem colocados à disposição dos estudantes no laboratório de Biologia do Ensino Médio. A EEJV é um campo de estágio curricular dos estudantes de ciências biológicas e apresenta uma estrutura bastante deficitária em recursos didáticos específicos para o ensino de biologia.

Para o desenvolvimento de modelos de Biologia Celular e Molecular como material didático de apoio para o Ensino Médio, cada um dos 3 grupos de estudantes do Curso de Ciências Biológicas da UNIFAL-MG tiveram reuniões quinzenais durante um semestre com o coordenador e elaboraram a pesquisa e montagem dos modelos.

Ao final dessa primeira etapa do projeto foi possível realizar a confecção de 7 modelos diferentes: tabuleiro da célula, membrana plasmática, mitocôndria, núcleo, modelo de transcrição, modelo de tradução e modelo da célula em papel higiênico. De cada tipo de modelo foram confeccionados cinco exemplares durante encontros semanais, ao longo de um semestre (fora do período normal de aula) com os grupos de alunos da EEJV, para compor o laboratório de Biologia da escola, de modo que eles pudessem auxiliar o aprendizado de novas turmas do primeiro ano e do turno noturno. Dessa forma, posteriormente as atividades puderam ser realizadas em grupos para o estudo de cada um dos modelos. A seguir serão apresentados o material e a metodologia utilizada para cada modelo.

\section{Tabuleiro da célula}

O estudo da célula ocorre desde o princípio da educação por isso sua compreensão deve ser facilitada. Para isso criamos um modelo de montagem a partir de peças separadas. Essa montagem ajuda na fixação das organelas e suas diferentes morfologias. Por isso a confecção do tabuleiro pode ajudar nessa compreensão, com a montagem a partir das peças separadas, fixadas com velcro, pode-se melhorar a compreensão das organelas e suas funções.

- Material usado:

Placa de isopor de $1,5 \mathrm{~cm}$ de espessura e $50 \times 50 \mathrm{~cm}$;

Uma cartolina branca;

Pedaços de velcro;

Lápis de cor;

Canetinha;

Papel "contact" incolor.

- Passo a Passo:

Na cartolina deve-se desenhar o modelo da célula animal ou vegetal. Desenhe todas as organelas e pinte. Em seguida cole a cartolina no isopor e cubra com papel "contact" incolor. Depois desenhe cada organela separadamente, pinte e cubra com papel "contact" incolor, colando velcro nas organelas (tanto no isopor quanto nas organelas isoladas). A figura 1 mostra o tabuleiro pronto. 


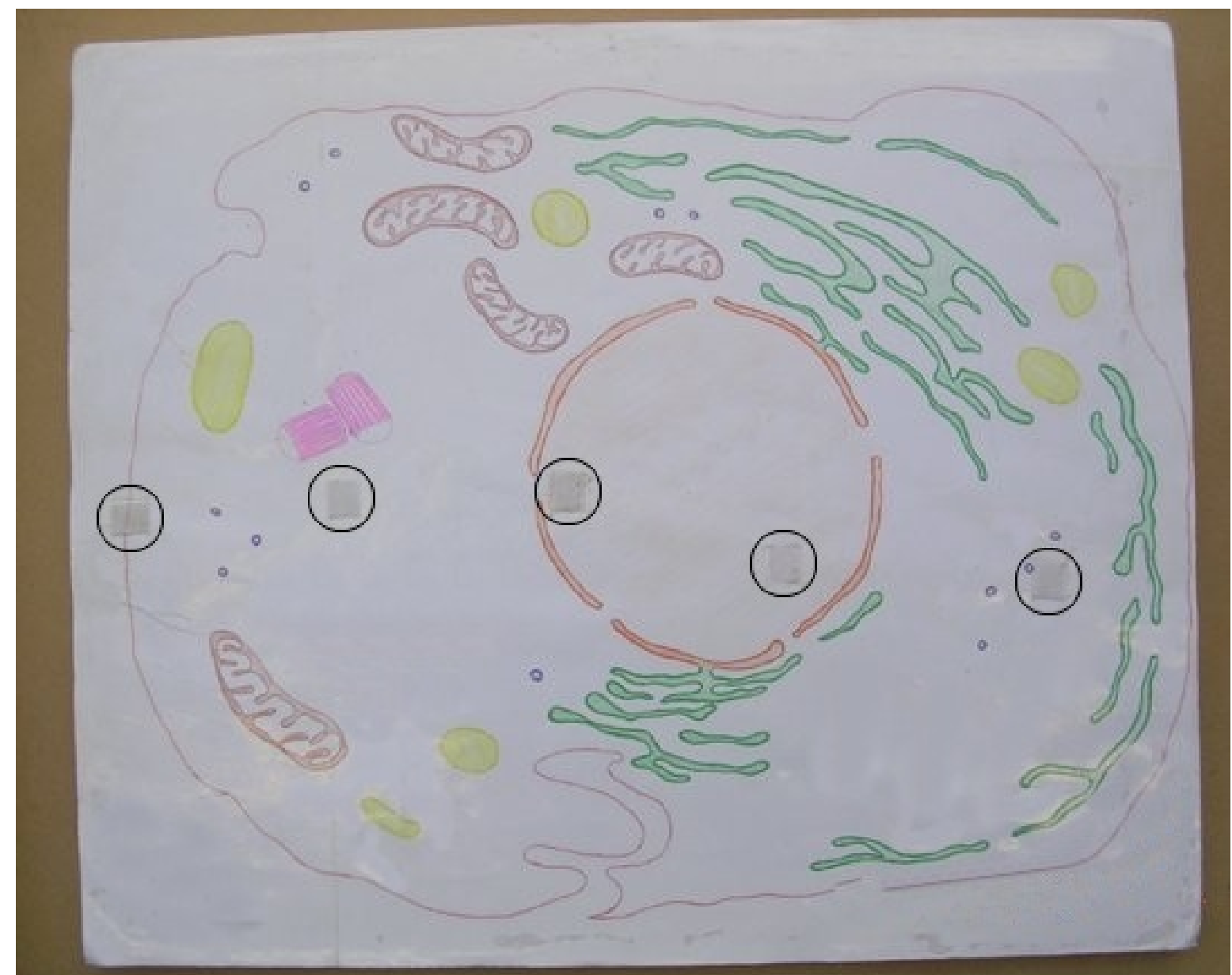

Fig. 1 - Tabuleiro da célula pronto, representando uma célula animal. 0 local de inserção das organelas, com os velcros, estão circulados na imagem.

- Como usar o modelo:

Nossa sugestão é usar o modelo na explicação de cada organela e ir montando a célula aos poucos, colando cada organela em seu espaço determinado e explicando suas funções.

\section{MEMBRANA PLASMÁTICA}

\section{- Materiais usados:}

1 bloco de isopor de $10 \mathrm{~cm}$ de altura, $12 \mathrm{~cm}$ de comprimento e $8 \mathrm{~cm}$ de largura; 20 bolinhas de isopor de $3 \mathrm{cmde}$ diâmetro;

Pedaços de isopor ( $4 \mathrm{~cm}$ de altura, $2 \mathrm{~cm}$ de comprimento e $2 \mathrm{~cm}$ de largura);

Arame maleável $1,5 \mathrm{~m}$ (cortados em pedaços de $5 \mathrm{~cm}$ );

3 cores de tinta (rosa, amarelo e laranja);

Cola branca;

Tinta;

Cola de isopor;

Lixa de madeira n0180;

Estilete e pincel fino; 


\section{- Passo a passo:}

Inicialmente, o bloco e as bolinhas de isopor são cortados e moldados com auxílio de estilete e lixa. As estruturas confeccionadas a partir dos pedaços de isopor correspondem às glicoproteínas e à proteína de canal. As bolinhas, previamente cortadas ao meio, vão constituir os fosfolipídeos juntamente com os arames. Essas estruturas são pintadas e após secagem da tinta, o modelo é montado.

Primeiro fura-se o centro do bloco de isopor, ligando um lado ao outro, com ajuda do estilete. Então começa com a colagem da estrutura correspondente à proteína de canal, ao redor do orifício feito no bloco. Depois são colocadas as bolinhas nas duas superfícies do bloco. Os arames, que funcionaram como as caudas dos fosfolipídeos, são inseridos nas bolinhas laterais, para sua visualização (Fig. 2).

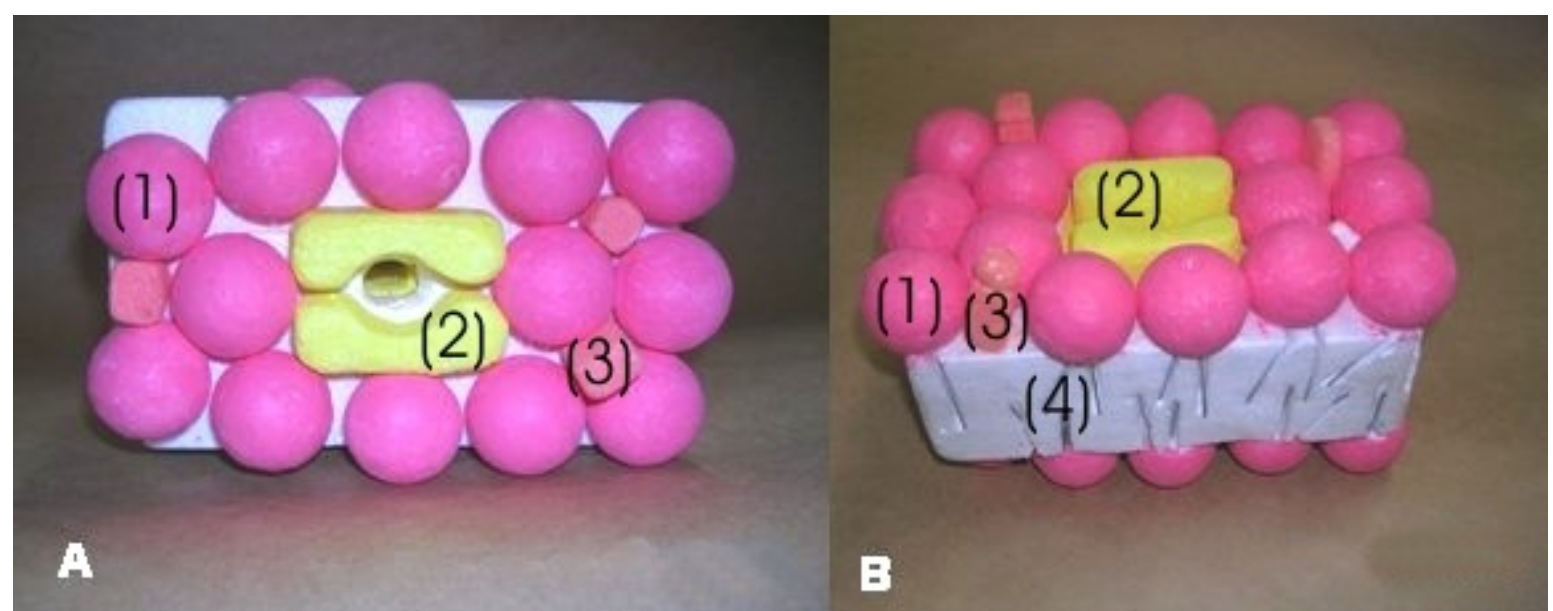

Fig. 2 - Modelo da membrana plasmática. A. Vista frontal (lado voltado para o meio extracelular). B. Vista bidimensional. As legendas indicam as cabeças hidrofílicas dos fosfolipídeos (1), a proteína de canal (2), as glicoproteínas (3) e as caudas apolares dos fosfolipídeos (4).

\section{- Como usar o modelo:}

Pode ser utilizado para auxiliar nas aulas relacionadas à membrana plasmática , bem como para suas funções. Ele facilita o entendimento do posicionamento das moléculas dispostas nas camadas da membrana.

\section{Mitocôndria}

- Material usado:

1 bloco de isopor de $20 \mathrm{~cm}$ de comprimento por $12 \mathrm{~cm}$ de largura e $8 \mathrm{~cm}$ de profundidade;

Estilete;

Lixa de madeira no 180;

Caneta;

Pincel fino;

Tinta;

Caneta hidrocor.

- Passo a passo: 
Com a folha de isopor de $8 \mathrm{~cm}$ de espessura marque os $20 \mathrm{~cm}$ de comprimento e 12 $\mathrm{cm}$ de largura desenhando com a caneta um retângulo. Corte este retângulo para obter a forma de um paralelepípedo, que representará futuramente a mitocôndria.

Lixe as laterais deste isopor e em um dos maiores lados desenhe com a caneta a membrana interna com suas cristas mitocondriais. Não se esqueça de deixar uns 2,5 $\mathrm{cm}$ entre a extremidade do isopor e a membrana interna, e quando for desenhar as cristas mitocondriais não fazê-las de pequena largura, pois pode quebrá-las quando for lixar.

Passe o estile na linha demarcada como membrana interna para começar a escavar a matriz mitocondrial. Lembre-se que não deve retirar todo o isopor, mas sim, aproximadamente uns $4 \mathrm{~cm}$ de profundidade.

Com as cristas e a matriz mitocondrial prontas dê o acabamento lixando a região interna da mitocôndria. Posteriormente, pinte a organela lembrando que deve diferenciar pela cor a região interna (matriz mitocondrial) da externa, necessitando de duas cores diferentes de tinta.

Quando a tinta secar represente na matriz mitocondrial, com o auxílio da canetinha hidrocor, os ribossomos, que podem ser simbolizados como pontos, e o DNA que deve ser uma circunferência pequena pintada ou um pedaço de linha preta formando um círculo, aderida ao modelo (isso dará um destaque em relevo para o DNA). A Fig. 3 mostra o modelo pronto.

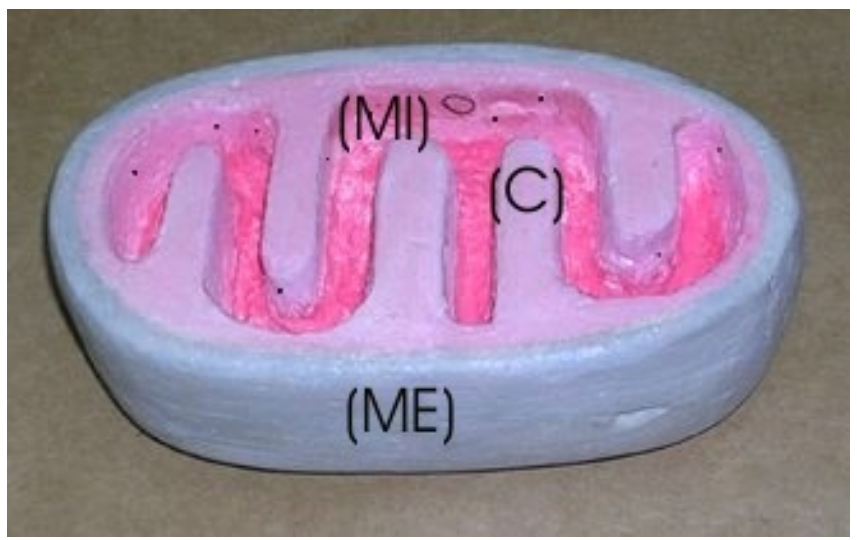

Fig. 3 - Modelo da mitocôndria. As legendas indicam a membrana externa (ME), a membrana interna (MI) com as cristas (C). Na matriz mitocondrial encontram-se representados o DNA mitocondrial (círculo preto) e os ribossomos (pontos pretos).

- Como usar o modelo:

Este modelo é um material importante para o aprendizado de biologia celular para os estudantes do Ensino Médio, já que demonstra a mitocôndria em todas as dimensões com suas características morfológicas.

Este modelo pode facilitar a associação com as características de uma bactéria, possibilitando o maior entendimento da teoria endossimbiótica, além de auxiliar na explicação das etapas para a produção de energia (ATP). 


\section{Modelo do Núcleo Interfásico}

- Material usado:

Meia bola oca de isopor tamanho grande;

Bola de isopor pequena;

3 pedaços de arame fino;

Barbante;

Retalhos de isopor;

cortador de isopor;

Cola;

Pincel largo;

Pigmento para pintura.

\section{- Passo a passo:}

A bola oca de isopor irá representar o envelope nuclear, que contém os poros nucleares, assim o primeiro passo será fazer pequenos furos na bola oca de isopor. Para isso esquente a ponta do arame e faça quinze furos em pontos aleatórios da bola. Em seguida pinte a parte interna da bola de uma cor e a parte externa de outra cor, para representar a diferença entre a membrana interna e externa do envelope nuclear.

Para a confecção do DNA será utilizado o arame e o barbante. Primeiramente passe cola no barbante, depois enrole o barbante no arame e deixe secar. Depois de seco enrole esse arame e pinte, deixando as pontas do arame sem barbante. Esse arame enrolado irá representar o DNA mais condensado, a heterocromatina. Para fazer o DNA menos condensado passe cola no barbante e o embarace, formando a representação da eucromatina visualizada ao microscópio óptico. Deixe secar e pinte em seguida.

O retículo endoplasmático rugoso será representado por peças de isopor que serão moldados com cortador de isopor como na figura 4. Essas peças serão coladas na borda da bola oca. A bola pequena de isopor irá representar o nucléolo. Essa bola deverá ser pintada e colada no fundo da bola oca.

Com todas as peças prontas comece colando o arame com barbante amarrado dentro da bola fixando as pontas do arame no isopor. Depois coloque o barbante enrolado, disperso por toda a bola. Cole as peças de isopor recortadas na borda da bola oca.

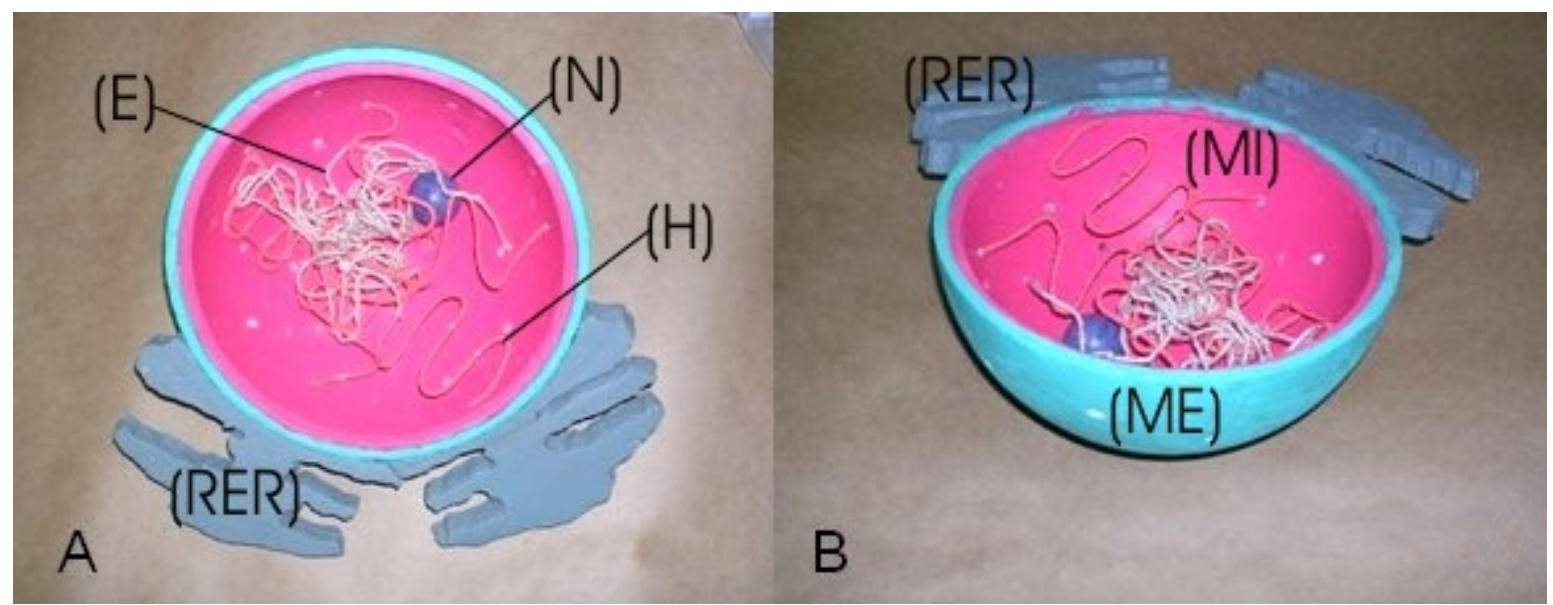

Fig. 4 - Modelo do núcleo interfásico. A. Vista frontal. B. Vista bidimensional. As legendas indicam o retículo endoplasmático rugoso (RER), em continuidade à membrana externa do núcleo (ME), e a membrana interna do núcleo (MI). No interior do modelo, o barbante emaranhado (mais claro) representa a eucromatina $(E)$, que é a cromatina menos condensada, e o barbante enrolado no arame 
representa a heterocromatina $(\mathrm{H})$, regiões mais escuras vistas ao microscópio óptico, além do nucléolo $(\mathrm{N})$.

- Como usar o modelo:

O professor pode utilizar esse modelo na explicação dos componentes nucleares, começando pelo envelope nuclear, até as formas mais condensadas e menos condensadas do DNA no núcleo interfásico.

\section{MODELO DE TRANSCRIÇÃO}

- Materiais usados:

Placa de isopor;

Massa de "biscuit";

Corantes (azul, amarelo, preto, verde e vermelho);

Pincéis;

Lápis de cor;

Tinta guache;

Cartolina;

Régua;

Lixa;

Cortador de isopor;

Cordão de algodão grosso.

- Passo a passo:

Numa primeira etapa, foram medidos e traçados na placa de isopor vários cubos de aresta 2,5 cm. Em seguida, utilizando o cortador de isopor, os cubos foram recortados para depois serem lixados. A massa de "biscuit" foi corada com os vários corantes, sendo que, cada cor deu origem a duas tonalidades uma mais clara e outra mais escura. Isso foi feito a fim de diferenciar os nucleotídeos do DNA (desoxirribonucleotídeos) dos do RNA (ribonucleotídeos).

Os cubinhos de isopor foram encapados com a massa de "biscuit" e foram colocados para secar por um dia. Depois de secos, eles foram perfurados no centro e, em seguida, foi passado um cordão pela cavidade, distribuindo-os em trincas. Nas outras faces foram colocadas as letras referentes a cada base nitrogenada, sendo que para os nucleotídeos do RNA ficaram os cubinhos de tonalidade mais clara.

- Como usar o modelo:

Com a cartolina, os lápis de cor, os pincéis e a tinta guache foi feito um painel de apoio (Fig. 5A), onde foram desenhadas a fita do DNA que servirá de molde e a fita do RNA recém sintetizado, mostrando a disposição em que as peças devem ser colocadas pelos estudantes, sendo inseridas no cordão guia de acordo com a fita molde estabelecida pelo professor ou por qualquer integrante da equipe. Dessa forma 0 aluno chegará a um painel completo (Fig. 5B). 


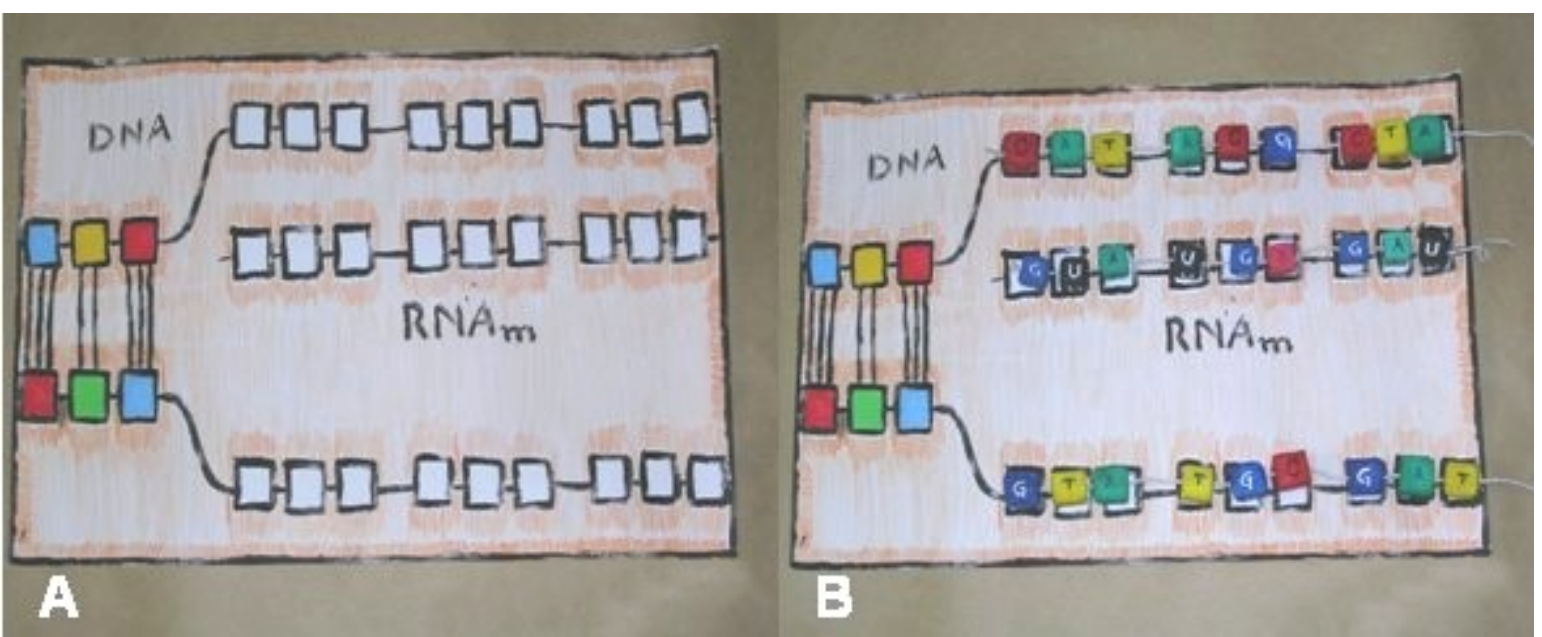

Fig. 5. Modelo de transcrição. A. Painel de apoio vazio. B. Modelo preenchido com os nucleotídeos (cubos de massa de "biscuit") de acordo com cada fita complementar.

\section{Modelo de tradução}

- Materiais usados:

Isopor ( $5 \mathrm{~cm}$ de espessura);

Tinta látex;

Corantes;

Estilete;

Lixa fina;

Cortador de isopor;

Pincel;

Canetinha hidrocor preta.

- Passo a passo:

Desenhou-se no isopor com canetinha preta o ribossomo, o RNA transportador, o RNA mensageiro (RNAm), os aminoácidos, e os nucleotídeos (na forma de cubos de isopor de aresta 2,5 cm, conforme já detalhado acima).

O RNA transportador e os aminoácidos ficaram como peças de encaixe. Os espaços onde se encaixavam os nucleotídeos foram perfurados com estilete e lixados para formar os códons (na fita de RNAm) e os anticódons (no RNAt). (Fig. 6). 


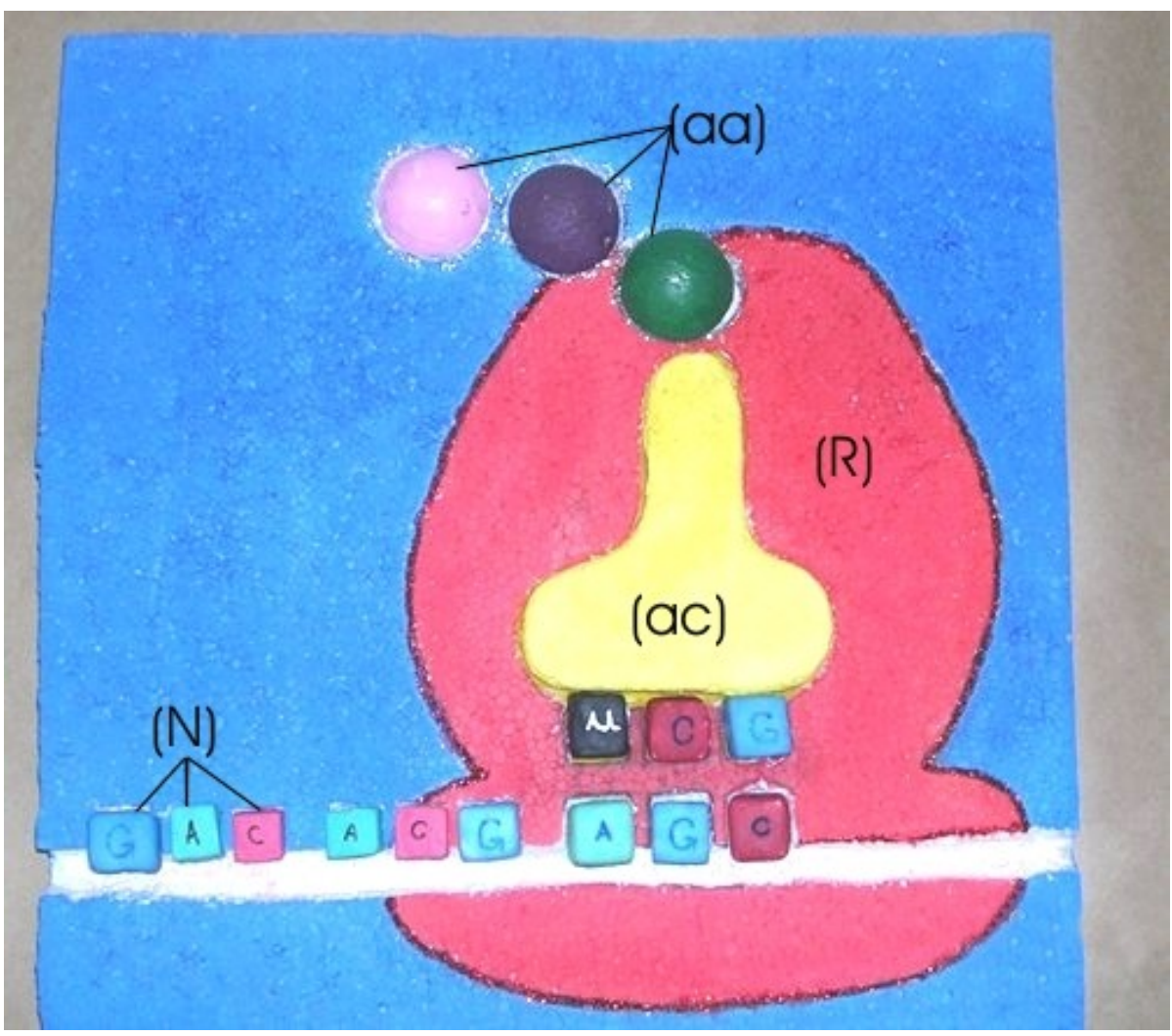

Fig. 6 - Modelo de tradução. As legendas indicam as duas subunidades do ribossomo $(R)$, os aminoácidos (aa) incorporados na molécula crescente de proteína, os nucleotídeos $(N)$ no RNA mensageiro ( $A, C, U$, G) e o anticódon (ac) no RNA transportador.

- Como usar o modelo:

O professor ou um dos integrantes da equipe escolhe uma trinca (cubinhos simulando os nucleotídeos do RNAm) e os encaixa no lugar apropriado, em seguida os integrantes da equipe deduzem qual será o anticódon do RNA transportador a ser colocado (cubinhos) e qual o aminoácido será então incorporado no polipeptídeo nascente. Várias combinações diferentes podem ser utilizadas para a simulação do mecanismo de tradução.

\section{Modelo da célula de papel higiênico}

- Material usado:

1 cartolina branca;

1 lápis para desenho de número 2;

1 placa de isopor (1,5 $\mathrm{cm}$ de espessura);

1 pincel de número 16 ;

1 tubo de cola branca $(80 \mathrm{~g})$;

1 tubo de cola para isopor $(40 \mathrm{~g})$;

Água;

Tiras de papel (pode ser tipo sulfite ou de caderno);

1 rolo de papel higiênico branco;

Tinta látex branca;

Tintas coloridas do tipo Guache;

Verniz incolor ou liquebrilho. 


\section{- Passo a Passo:}

Com o lápis para desenho, risque sobre a cartolina o formato da célula que deseja fazer. Cole a cartolina sobre o isopor, deixando para cima a parte desenhada na cartolina. Faça uma mistura de cola e água na proporção de 1:1. Enrole as tiras de papel (sulfite ou de caderno) em formato de canudos, estes serão colocados nas bordas da célula, para formarem a membrana plasmática. Molde o papel de acordo com cada estrutura que compõe a célula e cole-os sobre o desenho.

Após colados os papéis, aplica-se folhas de papel higiênico em toda a célula e com auxílio do pincel espalha-se a mistura de cola e água até que umedeça toda a área. Espera-se secar a primeira camada e novamente aplica-se o papel higiênico e a mistura de cola e água. Devem ser feitas de 4 a 5 camadas de papel higiênico, para que cubra bem as tiras de papel sulfite e dê efeito de alto relevo (Fig. 7A). Aguarde a secagem das camadas e pinte, dando uma demão de látex branco, para fazer a base. Depois de seca a base, pinte a célula e as estruturas que a compõem com tinta guache colorida. Depois de seca, para obter uma maior durabilidade do material aplique verniz incolor ou liquebrilho (Fig. 7B).

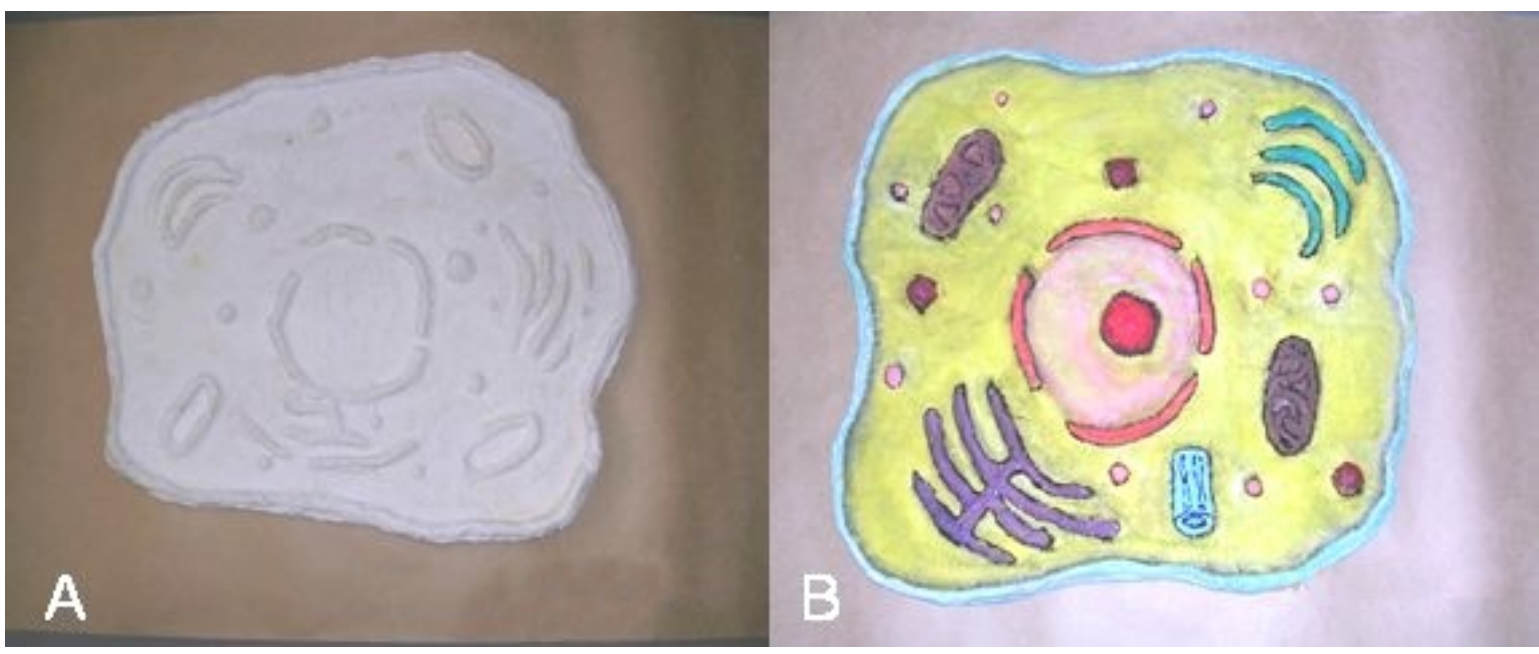

Fig. 7. Modelo da célula de papel higiênico. A. Um modelo sem pintar. B. Um dos modelos pintado pelos alunos da EEJV.

\section{- Como usar o modelo:}

O professor poderá utilizar o modelo pronto para ilustrar as organelas presentes na célula, enfatizando o tato como sentido para que os alunos descubram cada uma das organelas pelo seu formato ou poderá realizar com os alunos a atividade da construção do modelo, o que necessitará um envolvimento maior pelos alunos ao pensar na forma e tamanho de cada uma das organelas presentes na célula.

\section{RESULTADOS E DISCUSSÃO}

Durante o projeto foram elaborados 7 modelos com material de baixo custo, pelos 3 diferentes grupos de estudantes da UNIFAL-MG, participantes do projeto.

Antes da confecção e aplicação dos modelos sobre Biologia Celular e Molecular aos estudantes do primeiro ano do Ensino Médio (turmas 1, 2 e 3, com 50 estudantes aproximadamente) da Escola Estadual Judith Vianna, foram realizados encontros semanais com os alunos a fim de promover uma interação para iniciar o trabalho com os conteúdos teóricos, utilizando-se de conversas, discussões e questionamentos. Ao 
todo foram ministrados 12 encontros com duração de 50 minutos cada, para cada turma. Para avaliar o conhecimento prévio dos estudantes, nas aulas iniciais, foram lançadas perguntas sobre o assunto (biologia celular e molecular) através de uma conversa e um relato por escrito sobre o que eles entendiam sobre a célula. As respostas recebidas, na sua grande maioria, denotavam pequeno entendimento sobre esse termo básico da biologia. Abaixo estão apresentados alguns exemplos dos depoimentos escritos pelos estudantes (copiados exatamente como em seus relatos escritos, inclusive com erros básicos de ortografia e gramática):

"As celulas são organismo vivo pequenos que constituem as membranas".

"Um liqüidificador, uma enceradeira um automóvel ou uma celula são semelhante entre si no sentido de que todos necessitam de energia para funcionar".

"Célula é "pate" formadora de todos os tecidos e órgãos que compõe o corpo humano e outros. Também composta por cromossomos e água, não esquecendo do $\mathrm{CO} 2 "$.

"Célula é um composto muito importante na nossa vida."

"Célula é uma substancia que compõe nosso corpo."

"Parte do corpo que muitos acham inútil mas que é fundamental para nosso organismo."

Em reunião com os estudantes da UNIFAL-MG, resolvemos iniciar o tema com a exibição do documentário "vírus - uma ameaça invisível", da GNT. A idéia seria a de estimular a curiosidade dos estudantes para um tema atual e aplicado. Porém, a proposta não atendeu a nossa expectativa, pois foram verificadas dificuldades no entendimento por parte dos estudantes da turma inicial, devido ao grande número de termos pouco conhecidos pelos mesmos presentes no documentário.

Para suprir essa deficiência, o documentário foi substituído por uma analogia entre a célula (e suas organelas) com o corpo humano. Tal abordagem foi muito mais simples e apresentou melhor resultado, pois os estudantes participaram de forma dinâmica, o que fez com se interessassem pelo conteúdo a ser trabalhado.

Em reuniões quinzenais os materiais foram discutidos em cada um dos grupos de alunos da UNIFAL. As discussões foram muito interessantes, pois com os materiais prontos, pode-se verificar quais aspectos dos materiais poderiam ser melhorados, ou melhor explorados para estudantes do Ensino Médio em termos de conteúdo. Também foi discutida a facilidade em se explicar determinados temas em Biologia Celular e Molecular para estudantes do Ensino Médio através do auxílio dos novos materiais construídos.

Os novos materiais também foram testados inicialmente entre os estudantes dos grupos da UNIFAL. O teste foi posteriormente realizado com os estudantes dos outros grupos que não aqueles que fizeram o modelo. Os parâmetros analisados foram: durabilidade do material, facilidade de manuseio e transporte, tamanho (espaço para armazenamento), adequação ao conteúdo e à dificuldade do Ensino Médio e reprodutibilidade do fenômeno biológico em questão, sendo este um dos aspectos mais importantes, já que um modelo apesar de simplificado, não deve conter aspectos errados ou confusos com relação ao tema estudado. Neste ponto, Krasilchik chama a atenção à aplicação de modelos no ensino de biologia, pois estes podem simplificar demais os processos, ou mascarar processos que são dinâmicos e complexos em representações estáticas e simplistas [9]

A finalidade da montagem das peças pelo estudante é que ele aprenda a seqüência 
em que ocorre cada etapa dos mecanismos relacionados com a Biologia Celular e Molecular dos tópicos envolvidos. Por exemplo, o processo de tradução é de difícil entendimento e visualização pelo estudante. O material em terceira dimensão tem por finalidade auxiliar o estudante neste aprendizado, ilustrando melhor as etapas da tradução.

De acordo com a opinião dos estudantes participantes da UNIFAL-MG, estes se mostraram surpresos com a aceitação dos estudantes que compareceram às aulas sempre perguntando e tirando suas dúvidas. Segundo os estudantes, a experiência foi bastante gratificante, pois eles puderam ter um contato mais próximo com maneiras diferentes de ensinar e testar a sua didática. Para os estudantes que cursam a Licenciatura em Biologia, a experiência proporcionou um contato inicial com a sua carreira de professor.

Os estudantes universitários também diagnosticaram a falta de bagagem básica, necessária para o entendimento dos assuntos (por exemplo, átomos e moléculas) e propuseram aulas de assuntos mais básicos para sanar as dificuldades dos estudantes do Ensino Médio.

Foi observado que a confecção dos modelos, após as aulas teóricas sobre o mesmo, ajudou os estudantes do Ensino Médio a entenderem melhor o funcionamento de cada uma das estruturas, assim como foi dada uma oportunidade a esses estudantes de interagirem com os estudantes da UNIFAL-MG, gerando uma troca de conhecimentos e ansiedades sobre o Ensino Superior.

Os materiais e a metodologia utilizados para a montagem dos modelos foram adequados, visto que os estudantes não tiveram dificuldade na montagem dos mesmos. Os modelos tridimensionais mostraram-se bastante didáticos, já que os próprios estudantes relataram que obtiveram melhor resultado em suas aulas de Biologia, devido à maneira diferente pela qual foi ensinada a matéria (vide alguns relatos abaixo).

Os estudantes da escola relataram também que através deste tipo de atividade, fora da sala de aula, eles compreenderam melhor as informações do que nas próprias aulas de Biologia da escola, mostrando que atividades lúdicas e mais participativas dos estudantes (como a própria confecção de seu material didático), colabora para incentivar e trazer os conteúdos de Biologia mais próximos à realidade do estudante. Um relato de experiência com a construção de modelos tridimensionais ilustrando tecidos vegetais e confeccionados pelos próprios alunos também comenta o incentivo e motivação dos mesmos em confeccionar seus próprios modelos e ressalta a importância do aspecto lúdico e criativo em sala de aula e como parte do atributo de pesquisador e professor [10].

Um estudo com modelo tridimensional de contração muscular, desenvolvido por alunos de Licenciatura do curso de Ciências Biológicas, mostrou que o modelo possibilitou que os alunos sanassem as dificuldades com a disposição das estruturas, aproveitando melhor o conteúdo e, assim, favorecendo situações de ensino e aprendizagem baseadas em situações práticas para o aluno [11].

Alguns pontos relevantes foram apresentados pelos estudantes da UNIFAL-MG na última reunião de fechamento. Entre eles estão: o aprendizado foi melhor porque só os estudantes interessados participaram; o estudo a partir dos modelos é um processo mais dinâmico; enfocaram ser um modo mais prazeroso de aprendizagem; ficou mais fácil fazer associações com o cotidiano; os modelos tridimensionais auxiliam uma melhor visualização e compreensão dos conteúdos, normalmente microscópicos e abstratos; ficou mais fácil relacionar o todo com as partes e as partes 
com o todo; a linguagem utilizada pelos estudantes da UNIFAL-MG facilitou a aprendizagem, já que pareceu mais próxima aos estudantes da escola.

Da mesma forma como Almeida, 2003 [12], também foi percebido que o rendimento dos estudantes vai além das expectativas quando se trabalha com a turma de forma interativa e participativa, contextualizando sempre que possível. O envolvimento dos alunos nas atividades didáticas através do uso de modelos tridimensionais e ilustrações também foi responsável pelo melhora na capacidade de adquirir e guardar informações em comparação com métodos tradicionais em outros relatos [13].

Também foi percebido que à medida que os modelos foram sendo aplicados, foi notada uma nítida melhoria na capacidade assimilativa, associativa e de memorização do conteúdo pelos estudantes. Um estudo que envolveu a elaboração e avaliação de peças para construção de moléculas de DNA e RNA discute o alto potencial educacional desses modelos, possibilitando, também, o desenvolvimento de associações críticas de conceitos básicos com temas científicos atuais [14], o que poderia também ser aplicado acerca dos modelos aqui apresentados, desde que acompanhado de instruções para ajudar os professores a trabalhar temas atuais relacionados a cada modelo.

$\mathrm{Na}$ última aula dada, foi novamente perguntado aos estudantes o que eles entendiam pelo termo célula. Foi percebida uma grande diferença entre as respostas obtidas no começo do trabalho para as recebidas nessa última aula, sendo apresentadas respostas mais ricas e complexas. Algumas delas seguem abaixo, transcritas literalmente:

"Eu aprendi que o DNA passa as informações genéticas para os outros componentes da célula. Que a membrana plasmática permite o que passa e o que não passa pela célula e também protege a célula. A célula eucarionte tem o núcleo e a procarionte não. Eu também aprendi que a célula animal tem o centríolo e a célula vegetal não. Que o ATP é a energia para a célula."

"Aprendi que na célula a mitocôndria é responsável pela respiração celular, e que o Complexo de Golgi transforma e transporta as proteínas na célula, e que o DNA passa as informações do núcleo para a célula."

"DNA: ele passa informação. RNA: DNA passa informação para o RNA para ir até o ribossomo para ele produzir proteína. E que também que o papel da membrana plasmática é de selecionar substâncias que vão entrar ou sair da célula."

"É a unidade estrutural dos seres vivos".

"A celula são semelhantes entre si no sentido de que todas necessitam de energia para funcionar, a celula tem um núcleo que é praticamente o celebro da celula sem o celebro o ser humano não vive é e a mesma coisa com a celula sem o núcleo a celula não existe".

"Existem milhares de células espalhadas pelo nosso corpo, cada uma com sua função. Existem células procariontes e eucariontes. Nessas células existem várias organelas".

Opinião dos estudantes da Escola Judith Viana sobre o projeto:

"Eu achei que as aulas foram bem criativas e renderam muito, todos prestavam muita atenção e no final tiramos bastante proveito da explicação".

"Todos os estudantes puderam aprender mais e ter mais capacidade de distinguir e saber mais sobre a célula. Com essas aulas extras, conseguimos aprender mais e 
esclarecer várias dúvidas sobre o assunto tratado, as explicações foram bastantes claras, todas as dúvidas esclarecidas e aprendizagem melhor".

Em conversas informais com o Diretor da escola, o projeto e a iniciativa dos estudantes foi muito bem avaliada por ele, que se mostrou bastante satisfeito com o resultado do projeto e o estímulo dos estudantes da escola.

A experiência descrita neste artigo reflete a importância de um constante repensar por parte dos profissionais envolvidos com a educação, quando se trata da elaboração de materiais didáticos a serem utilizados no Ensino Médio.

Esses relatos denotam que a aplicação dos modelos foi eficiente tanto na fixação das teorias básicas quanto no aumento do interesse dos estudantes pela matéria, consistindo uma estratégia alternativa interessante para aplicação tanto no Ensino Médio como no desenvolvimento das habilidades do professor em formação. 


\section{CONCLUSÃO}

A elaboração de modelos produzidos pelos estudantes do curso de Ciências Biológicas da UNIFAL-MG buscou promover a aprendizagem construtivista, proporcionando ao estudante do primeiro ano do Ensino Médio momentos de reflexão e criação. A proposta foi resgatar atividades que levem o estudante ao mundo da biologia de forma mais atraente e que estimulem a busca de novas descobertas e informações.

A utilização desses modelos mostrou, tanto pela observação das aulas como pelas avaliações feitas pelos estudantes do Ensino Médio, que a maioria dos estudantes manifestou grande interesse ao longo das aulas através de uma participação ativa e, conseqüentemente, uma interação com os estudantes da UNIFAL-MG.

A partir da comparação dos resultados obtidos podemos concluir que as informações passadas foram assimiladas pelos estudantes do Ensino Médio. O projeto causou uma grande motivação nos estudantes, que não se limitou apenas à sala de aula. Isso foi comprovado através de resumos e artigos que nos foram apresentados, retirados da mídia, mostrando que eles tiveram interesse em saber e procurar mais sobre o assunto.

Pode-se verificar que neste projeto o trabalho dinâmico com os estudantes, através das atividades desenvolvidas com modelos concretos de teorias abstratas levou a um maior interesse pelo conteúdo, o que sem dúvida contribuiu para uma melhor aprendizagem.

Outra observação de grande importância é a formação de profissionais que estejam preparados para atuar, ou pelo menos que tenham uma visão crítica, no processo de ensino e aprendizagem. Para os estudantes de graduação que desenvolveram este projeto a experiência foi de grande importância para a formação profissional, principalmente no campo da licenciatura, uma vez que puderam avaliar o seu próprio desempenho e conhecer as dificuldades vividas em sala de aula.

\section{AGRADECIMENTOS}

Agradecemos a Pró-Reitoria de Extensão da UNIFAL-MG pelo apoio ao projeto. 


\section{REFERÊNCIAS BIBLIOGRÁFICAS}

[1] L.C.C. Aguiar (2003). Modelos biológicos tridimensionais em porcelana fria alternativa para a confecção de recursos didáticos de baixo custo. In: Anais II Encontro Regional de Ensino de Biologia, Niterói .pp. 318-321.

[2] S.S.P. Souza, et. al. (2003) Atividades práticas: um valioso instrumento no Ensino Fundamental. Revista Participação, UnB, 12,13-16.

[3] I.S.R. Pasquali, A.L. Amorim (2000). Atividades práticas: despertando o interesse pelas aulas de Biologia. $52^{\mathrm{a}}$ Reunião Anual da SBPC. Brasília - DF..

[4] E. L. S. Loreto, L. M. N. Sepel (2004) Relação entre membrana plasmática e citoesqueleto na forma celular: um estudo com modelos. Revista Brasileira de Ensino de Bioquímica e Biologia Molecular.: http://sbbq.iq.usp.br/revista/pesq.php.

[5] S. Linhares, F. Gewandsznajder (1997) Biologia Hoje, v.1. Ática:. São Paulo, pp.105-127.

[6] A.C. Marcondes, D. A. Lammoglia (1994) Biologia ciência da vida. Atual: São Paulo.

[7] B. Alberts, et. al. (1997) Biologia molecular da célula. $3^{\circ}$ ed. Artes Médicas: Porto Alegre.

[8] H.F. Carvalho, S. M. Recco-Pimentel (2001) A célula 2001. $1^{\text {a }}$ ed. Manole: São Paulo.

[9] M. Krasilchik (2004). Prática de Ensino de Biologia. 4a. Edição. Editora da Universidade de São Paulo: São Paulo.

[10] G. Ceccantini (2006) Os tecidos vegetais têm três dimensões. Rev. Bras. Bot. 29(2), 335-337.

[11] S.S.de Oliveira (2005) Concepções alternativas e ensino de biologia: como utilizar estratégias diferenciadas na formação inicial de licenciados Educar 26, 233-250.

[12] J.M.S. Almeida (2003). Construindo a célula animal em sala de aula. In: Anais II Encontro Regional de Ensino de Biologia, Niterói pp. 382-384.

[13] Y. Rotbain, G. Marbach-Ad, R. Stavy (2006) Effect of bead and illustrations models on high school students' achievement in molecular genetics. Journal of Research in Science Teaching 43(5), 500-529.

[14] L.M. Beltramini, et. al. (2006) A new three-dimensional educational model kit for building DNA and RNA molecules: development and evaluation. Biochem. Mol. Biol. Educ. 34(3), 187-193. 